\title{
Justum Ad Bellum \& Israel's 2006 Attack on Lebanon: An Examination of Just War Principles
}

\author{
Saikou Kawsu Gassama ${ }^{1}$, Mansoureh Ebrahimi ${ }^{1} \&$ Kamaruzaman Yusoff $^{1}$ \\ ${ }^{1}$ Faculty of Islamic Civilization, Universiti Teknologi Malaysia \\ Correspondence: Mansoureh Ebrahimi, Faculty of Islamic Civilization, Universiti Teknologi Malaysia, 81310, \\ UTM, Johor Bahru, Johor, Malaysia. Tel: 60-755-10230. E-mail: mansoureh@utm.my, suriebrahimi@gmail.com
}

Received: May 16, 2018

doi:10.5539/ass.v14n8p68
Accepted: June 8, 2018 Online Published: July 27, 2018

URL: https://doi.org/10.5539/ass.v14n8p68

\begin{abstract}
Due to the continuum of Hezbollah rocket attacks from southern Lebanon, Israel attacked Lebanon in July 2006, devastating infrastructure and causing substantial loss of Lebanese lives. This paper provides a detailed documented analysis that examines the applicability of Just-War concepts and criteria for the attack with a view to determine whether or not it was morally justified according to accepted international standards. After reviewing contemporary expositors, our analysis of Just-War criteria according to traditions stemming from St. Augustine and St Thomas Aquinas indicate that although a few criteria fit Just-War Theory, Israel had overwhelmingly failed to satisfy requisite conditions for both jus ad bellum and jus in bello, thereby rendering their Lebanon incursion unjustifiable, and therefore an unjust war.
\end{abstract}

Keywords: Just-War Theory, jus in bello, jus ad bellum, proportionality, just cause, last resort

\section{Introduction}

The theory of justum ad bellum or "just war" was first propounded in the West by St. Augustine as he sought to explain how "war" could be "just" in Christian ethics. Justum bellum is correctly translated as "justified war" instead of the common usage of "just war" (Ramsey, 1992). Some writers such as Richard Sorabji have indicated that the contemporary criteria of jus ad bellum and jus in bello had its origins in pagan antiquity in the writings of Greek Philosophers such as Plato and Aristotle and Roman philosopher, Cicero (Sorabji, 2006). St. Augustine's exposition seemed to have influenced the Western Christian thought on the issue of "just war." The notion of just war can be addressed from two perspectives namely the jus ad bellum and jus in bello. The jus ad bellum deals with the fundamental questions of when it is just to start a war. The jus in bello on the other hand addresses the questions of how just is the war conducted. The Christian tradition has identified certain criteria in determining whether initiating a war is just or not, all of which fall under the jus ad bellum category (Sorabji R. \& Rodin, 2006). These criteria as generally agreed in just war theory literature and also re-affirmed by American Catholic Bishop's 1983 Pastoral letter on just war theory, which are: 1) just cause 2) last resort 3) right authority 4) open declaration 5) achievable aims 6) proportionality and 7) discrimination (Holmes, 1992; O'brien, 1992; Sorabji \& Rodin, 2006). The jus in bello tend to be concerned more with the nature of war in two main aspects of proportionality and discrimination.

The aims of this paper is to examine the applicability of the concept of just war and its criteria to the Israeli attack on Lebanon between July and August 2006 so as to determine whether it was just or not. The paper argued that while a few criteria of the just theory was fulfilled by the Israeli war on Lebanon, it failed to satisfy most of the conditions thereby rendering it an unjust war. A war is justified when it is characterised by jus ad bellum. However a justified war is not necessarily a just war. For a war to be just, it has to be characterised by both jus ad bellum and jus in bello (Holmes, 1992).

St Augustine postulates that the objective of war should be to obtain peace. For Augustine order is a necessary prerequisite for peace, and therefore fighting war (or killing) in order to achieve order is consistent with Christian believe; and that true peace could only be obtained in the City of God. Augustine expounded upon the just conduct of war (jus in bello), which includes moderation in conducting war, for example, humane (compassionate) treatment of prisoners of war. Such a disposition has no room for excesses or disproportionality. In order to understand just war, Augustine postulated that the degree of the wickedness of the adversary determines the justness of the cause (Bowyer, 2008). Drawing on St Augustine, Gratian and other scholars, 
Aquinas discussed war in his Summa Theologiae as an instrument of defence for the protection of persons, community or property. The objective of the war must be to avoid evil and promote the public good. War could also be fought, according to Aquinas, for the purpose of redressing wrongs inflicted. Aquinas indicated that the justification for is dependent upon fulfilment of the following three conditions:

"It must be waged by the due authorities, for those who may lawfully use the sword to defend a commonwealth against criminals disturbing it from within may also use the sword of war to protect it from enemies without. But the cause must be just (those whom we attack must have done some wrong which deserves attack), and those waging war must intend to promote good and avoid evil. It must be waged by the due authorities, for those who may lawfully use the sword to defend a commonwealth against criminals disturbing it from within may also use the sword of war to protect it from enemies without. But the cause must be just (those whom we attack must have done some wrong which deserves attack), and those waging war must intend to promote good and avoid evil" (McDermott, 1989).

\section{An Application of the Concept of Just War to the Israeli War on Lebanon}

According to the just war theory, competent authority has to declare war for it to be justified. This declaration precludes any private authority or person. This generally falls under the jurisdiction of a sovereign or occasionally a body such as legislature or executive in some cases. Declaration by competent authority gives legitimacy to the war. The Israeli attack on Lebanon followed pronouncements by the Israeli Prime Minister, Ehud Olmert, calling on Hezbollah to release the two captured soldiers, and also warning of severe consequences. Ehud Olmert branded Hezbollah capture of Israeli soldiers as declaration of "war on Israel" which would merit a punitive military campaign. Hezbollah refused to release the prisoners and Israel declared war on them. This declaration of war fulfils two criteria of just war, that is to say that war is to be declared by the "right authority", and that it should be an "open declaration."

The just war theory propounds that for a war to be considered just it should have the right intension or motives. The war should aim to achieve peace not for its own sake. Such objectives should also have reasonable chance of success before declaration of the war. It is doubtful if the intension of the Israeli's were aimed at the securing peace since they did not explore that avenue. It seems the Israelis were sceptical of fulfilling the war objectives from the very out set. Hence, it was not surprising that the Israeli army failed to achieve the objectives of the military campaign. The Israeli objectives of the war on Lebanon and Hezbollah were:

1) To free the two captured Israel soldiers from Hizbullah captivity (identified as Ehud Goldwasser and Eldad Reger);

2) To root out Hizbullah infrastructure and basses;

3) To cut off Hezbollah arms supply line reportedly from Syria and Iran; and

4) To prevent and Interfere with terrorist activity against Israel (Erlanger, 2007; Fattah, 2006)

The failure of the Israeli army to achieve its war objectives in Lebanon was expressed by Israeli army Chief of Staff, Lieutenant Dan Halutz as thus: "we were not successful in reducing the short-range rockets on Israel's north until the ceasefire," which came into being after 34 days of fighting (Erlanger, 2007). Some of the war objectives of Israel were unrealistic from the onset, and the probability of fulfilling them was negligible.

Needless to say, the chance of Israel army achieving the objectives of the military campaign were idealistic and unrealistic, to say the least. The first objective of destroying Hezbollah infrastructure and bases has presumably the slimmest chance of success. It should be noted the Hezbollah as armed group emerged in 1985 as a response to Israeli occupation of southern Lebanon in 1982. The raison d'être behind the existence of the Hezbollah institution was to resist militarily the Israeli occupation of Lebanese territory (Levitt, 2015) Hezbollah has gradually turned itself into permanently trained, disciplined, well-organised and powerful guerrilla movement overtime with assistance from countries notably Iran and Syria. Hezbollah, meaning "the Party of Allah (God)," perceives itself, as well as many Lebanese do, as the "defender" of the land and people of Lebanon against the Israeli onslaught and territorial expansionism in the Middle East. It is important to note that Israelis had taken over Arab lands in previous wars such as 1967, 1969 and 1973 belonging to Egypt, Syria and Jordan (Levitt, 2015). Hezbollah had been fighting against Israel occupation from 1985 to 2000 when the latter finally withdrew their side of the border. One wonders if Israel could not conquer the Hezbollah in over 20 years at a time when they were armed with less sophisticated equipment, how they could destroy them in a short quick war of a month's period.

Moreover, Hezbollah has been looking for an opportunity to free a lot of their members and other Lebanese citizens have been taken into Israeli custody during their occupation. In spite of the Israeli occupation of 
Lebanon for almost two decades they failed to defeat or destroy the Hezbollah infrastructure until their withdrawal. Hence it is very unlikely that they could fulfil that objective. Therefore, it is apparent that Hezbollah would continue to exist in the current status quo regardless of the war or its outcome.

The objective of freeing the two captured Israeli soldiers probably has the highest chance of success if they knew their location. If this was the sole objective of the war, then it was achievable diplomatically without any war or bloodshed through prisoner exchange demanded by Hezbollah but the Israelis opted for war. Stopping Hezbollah arms supply lines from Syria and Iran looked pretty impossible in a region with porous borders. Israel's existence in the region is an anomaly as it does not have any friends in the neighbourhood and therefore difficult to see this supply line stopping. Consequently, the supply line could not be cut off.

The net result was that Israel failed to achieve its war aims. The two captured soldiers remained in Hezbollah hands. Israel hope to show the Lebanese that Hezbollah was responsible for the "total" destruction of their country. Rather than destroy Hezbollah's infrastructure or turn the Lebanese against them, the war made a hero out of Hezbollah who claimed victory for themselves (Lee, 2006). Though United Nations Security Council Resolution 1701 called for Hezbollah disarmament, it did not provide the modus operandi of how it should be implemented. Moreover, the former UN Secretary General stated that disarming Hezbollah was not the direct Mandate of the UN (Levitt, 2015); and hence United Nations Interim Force in Lebanon (UNIFIL) could not engage in disarmament process (Institute, 2007).

The just war traditions requires a "just cause" as a precondition of entering war. This tradition, following St. Thomas Aquinas, recognises two main reasons for justifying war namely self-defence and rectification of a committed wrong. This rectification process normally takes the form of punitive or restitutionary approach. Aquinas argued that just like the rulers have legitimate right to use their authority to punish criminal who disturb the peace; in the same vein they have legitimate rights to protect their states against external aggression (or enemies). St. Thomas Aquinas stated: "just as rulers rightly use the sword in lawful defence against those who disturb the peace within the realm, when they punish criminals...so too they rightly use the sword of war to protect their polity from external enemies (Finnis, 1996)." This type of war has a just cause as they are intended in rectifying or correcting wrongs. Looking at the Israeli-Lebanon war, on this principle has a just cause. The war, on this occasion, started after Hezbollah attack on Israeli positions killing eight, capturing two and wounding some. Responding to aggression from an enemy has traditionally been accepted as part of a "just " cause for entering war; hence this constituted aggression (Turner, 1984) and therefore fair for Israel to adopt self-defence and demand the freedom of captured soldiers. The war in this aspect seems to have some grounds that could be construed as just cause on the part of the Israelis.

A fundamental principle required for a war to be considered just is that all other avenues should be explored in order to avert war. This means that war should be entered into as a last resort after exhausting other alternative ways of peaceful dispute resolutions through diplomacy. Did the Israeli use war as a last resort? Were alternative methods of resolving conflict explored? Affirmative answers to the aforementioned questions are required to certify the war as just. Hezbollah demanded negotiation to exchange Lebanese prisoners incarcerated in Israeli jails for the captured Israeli soldiers. The Israeli's rejected any form of prisoner exchange or negotiation which they perceived as yielding to "terrorist" demands.

It is also important to note that the US President, George Bush, branded the Israeli attack on Lebanon as "war on terror" (Bush, 2006; Pressman, 2006). In fact on 26 July 2006, the USA and Britain had used their political leverages at the Security Council to block an international effort to bring about an immediate ceasefire during Israeli war on Lebanon, which allowed Israel to conduct some strategic military actions in southern Lebanon (Reynolds, 2005). It should be pointed out that Israel had previously engaged in prisoner exchange with both Hezbollah in 2004 (two years before the war) as well as Hamas. Hezbollah considered Lebanese prisoners as people detained arbitrarily or imprisoned without trial while some "disappeared" or "abducted." The Hezbollah objective of capturing the soldiers was to gain political capital in order to set up a prisoner exchange negotiation with Israel believing that it would enhance their bargaining position. Nevertheless, the Israeli authorities, under the leadership of the Prime Minister, Ehud Olmert, denounced this process by declaring Hezbollah attack as "act of war" and warned of negative consequences. Israeli's did not give much chance to an alternative negotiated or mediated peaceful solution to the crisis but only claimed that they do not negotiate with terrorists. Accordingly, Israelis opted for open war with Hezbollah and Lebanon which shut down the avenue of resorting to war as a last resort in accordance with just war ethics.

The principle of proportionality is one of the two principles that fall under the purview of jus in bello. The proportionality principle requires that the nature or conduct of war should be proportionate to the harm or 
damage inflicted. Applying this criterion of proportionality to the Israeli war on Hezbollah and Lebanon tend to show that this principle is presumably the most flouted of all others. The war ensued following the capture of two Israeli soldiers by Hezbollah who demanded prisoner exchange with Lebanese incarcerated in Israeli prisons.

Hence, Israel declared its "war on terror" by initially targeting Hezbollah positions with aerial bombings as well as precision guided missiles. It appeared Israel was getting into a more complicated and protracted guerrilla war with battle hardened Hezbollah described by one Israeli newspaper, Haartz, as "trained, skilled, well-organised, and highly motivated infantry that was equipped with the cream of modern weaponry from the arsenals of Syria, Iran, Russia and China (Tal, 2006)." Hezbollah has been described by the Canadian authorities as "one of the most technically capable terrorist groups in the world (Levitt, 2015)." The former Israeli Prime Minister acknowledged the fact that the Israelis were responsible for the creation of Hezbollah in Lebanon "when we entered Lebanon... there was no Hezbollah. We were accepted with performed rice and flowers by the Shia in the South. It was our presence there that created Hezbollah (Dijxhoorn, 2017; Gleis, 2011; Norton, 2009)." A lot of has changed since then, and Hizbollah has become a resilient and effective guerrilla out-fit that create too many problems for the IDF and Israel.

Israel intended to win the war at all cost to avoid humiliation by inflicting the most severe damage or destruction possible. Hence they embarked upon systematic way of carrying out mass destruction with the express purpose of subduing Hezbollah. By deliberately targeting civilians, Israeli military strategists aimed to score one over Hezbollah by turning the civilian population against them. It was hoped that the Lebanese people will blame Hezbollah for bringing destruction on Lebanon. However, this achieved the opposite objectives result as it turn Hezbollah into heroes and defenders of the Lebanese land and people in spite of the staggering number of deaths of 1,120 reported by the Lebanese Ministry of Health (Tal, 2006). With the bombing of civilians in Qana, Al Qaeda's Ayman al-Zawahiri issued a video statement retorting that attack and indicating al-Qaeda's willingness to fight against them. "As they attack us everywhere, we will attack them everywhere. As they have joined forces to fight us, our nation will unite to fight them... the shells and rockets which tearing the bodies of Muslims in Gaza and Lebanon are not purely Israeli. They are produced and financed by all the countries of the Crusader alliance...we cannot just watch these shells as they pour wrath on our brothers in Gaza and Lebanon and sit back in submission" (Bellamy et al., 2007). In analysing 2006 war, Anthony Cordesman, Professor of War Studies at the Washington Centre of Strategic and International Studies, condemned Israeli military strategic approach that "carelessly seek immediate tactical advantage at cost of major strategic risks and penalties...is stupid and dangerous. Creating more enemies than you kill is self-defeating; making it politically and ideologically impossible to end a war and so is spreading new levels of anger and hatred to other countries and/or factions (Cordesman \& Sullivan, 2007)." Professor Cordesman's analysis was also rightly reflected elsewhere including Iraq where the so-called firebrand Iraqi Shi' ite cleric Muqtada al-Sadr mobilised a large demonstration chanting "Death to Israel", and condemning the "Evil Triangle", believed to be in reference to the USA (and western supporters like UK), Israel, and Arab states that supported the Israeli military campaign in Lebanon (Norton, 2009). Anthony Cordesman sums up his perspective on the Israeli war on Lebanon as thus: "is more than a horrifying human tragedy; it is a brutal lesson in changing nature of modern war...a lesson that applies just as much to Iraq, Afghanistan, and the war on terrorism as it does to the fighting in Lebanon. The Lesson is simple: limited wars must be fought in ways giving avoiding collateral damage and civilian casualties at least as much priority as destroying the enemy (Cordesman \& Sullivan, 2007)." In fact the Israeli military campaign strategy as executed during the war on Hezbollah and Lebanon was nothing short of total war manifested in the large scale indiscriminate destruction of lives, infrastructure and properties-both military and civilian- (Young, 2010).

The UNDP projected about 35,000 homes and businesses were destroyed in Lebanon. Also about a quarter of the Lebanese road bridges or flyovers were dismantled with an estimated total loss of about $\$ 15$ billion (Cordesman \& Sullivan, 2007). Some 900,000 and 300,000 people were internally displaced in Lebanon and Israel respectively (Engdahl \& Wrange, 2008). What is more, the Israeli death was over a hundred. This wanton destruction of lives and properties to secure the release of two captured soldiers was indeed excessive and disproportionate. This was acknowledged by Jan Egeland, the UN Humanitarian Chief, who condemned the Israeli offensive as "disproportionate...a violation of international humanitarian law" and also criticised Hezbollah for blending with civilians (Press, 2006). It has been pointed out that the unnecessary and excessive civilian casualties and damage to the Lebanese economy made some war analysts to charge that Israel had seriously mismanaged the war (Cordesman \& Sullivan, 2007).

IDF fired excessive artillery shells in southern Lebanon, which inflicted extensive damage to civilian infrastructure, lives and properties (Arkin, 2011). It must be pointed out that a majority of the Security Council 
members recognised Israeli right to self-defence under Article 51 of the UN Charter in the wake of Hezbollah attack. Nevertheless a majority of Security Council members also felt that the Israeli response was excessive and disproportionate to the attack. "The fighting lasted for 34 days, during which Hezbollah launched an estimated 3,970 Katyusha rockets on military and civilian targets in Israel, including the city of Haifa, killing 162 Israelis, wounding 4,000. Approximately 1,000 Lebanese were reported killed, and 4,000 wounded" (Berman et al., 2012). Four days into the fighting, the Human Right Watch (HRW) issued a statement on 16 July 2006, indicating that the Israeli's failed to "take all feasible precautions to protect civilians" during its targeting of Hezbollah infrastructures (Berman et al., 2012). HRW in its report "Fatal Strikes: Israel's indiscriminate attack against Civilians in Lebanon," further accused Israel of perpetrating war crimes and documented what it called "serious violations of International Humanitarian Law (laws of war) (Berman et al., 2012).

Jus in bello requires the protection and immunity of civilians during war. This discrimination of non-combatants is essential component for any war to be considered just. Discrimination principle requires desisting from deliberate targeting of civilians, which is often done by parties so as to maximise damage and fear forcing surrender or an end to hostilities. The principle of discrimination would require that if civilian casualties are unavoidable, they should be minimised at all cost. The Israelis have been noted for lack of discriminating military from civilian targets, and deliberately targeting civilians and civilian infrastructure claiming Hezbollah rockets have been launched from them or their vicinity(Engdahl \& Wrange, 2008; Reynolds, 2005; Saleh, 2007). Residences of Hezbollah political leaders and Hezbollah TV stations were also considered military targets and bombed accordingly. The IDF targeted civilian infrastructure to attain military advantage by forcing Hezbollah to surrender in view of total destruction inflicted on the Lebanese people (Matthews \& Institute, 2008). Israel held Lebanon responsible for Hezbollah attack due to lack of implementing UN Resolution 1559. Israel army chief of staff Lt. General D. Halutz warned of serious destructive consequences if the two captured soldiers were not handed over IDF: "If the soldiers are not returned, we will turn Lebanon's clock back 20 years" (Engdahl \& Wrange, 2008; Young, 2010). Halutz further indicated that the war was also "open-ended...nothing is safe [in Lebanon] as simple as that" (Shalom, 2006). This objective points to a systematic way of targeting civilians to maximise damage typical of "total" war which undermines fundamental principle s of just war. Civilians are entitled to immunity from such obliteration bombings under natural law (Ford, 1970) but such rights were completely violated by the IDF.

Similarly, IDF deliberately targeted the United Nations observer mission killing four UN officers even after UN had persistently given prior warning and information to the IDF about UN presence at the location. The then UN Secretary General, Kofi Annan, indicated that the UN Mission was clearly marked, and the IDF was duly informed about it; and that IDF subsequently hit the structure after some twenty such earlier attempts indicating that it was deliberately targeted (Reynolds, 2005; Saleh, 2007). Civilian targets such as bridges and roads, electrical facilities, were destroyed. This has inflicted severe harm on the civilian population. Bombed roads and fuel supply lines lead to closure of hospitals and impeded distribution of much needed humanitarian aid (Bouckaert et al., 2007). The devastating attacks on civilians and civilian targets were acknowledged by International Crisis Group. According to the International Crisis Group, Israel had targeted:

"economic infrastructure bearing little or no relation to Hizbollah; the airport (far more than necessary to meet any reasonable military goal); Beirut's entire southern suburb (far beyond Hizbollah's infrastructure); the ports of Beirut and Jounieh (in Christian territory); industrial plants; bridges leading to the south (presumably in order to cut it off, interfere with Hizbollah's resupply, prevent militants from moving the Israeli captives around and alienate the local population, but all this at enormous humanitarian cost); [and] the army, including check points in Christian areas (highly questionable since the army has stayed out of the conflict, avoided using its anti-aircraft capacity despite the onslaught, focused on maintaining domestic law and order and, above all, remains the only instrument capable of extending the state's authority over the country as a whole"(Shalom, 2006).

In the same vein, Kenneth Roth, the executive director of Human Rights Watch, noted that "International humanitarian law permits attacks on infrastructure only if it is making an effective military contribution, and the military benefits of its destruction outweigh the civilian costs. That case is difficult, if not impossible, to make for the extensive attacks on electrical facilities, bridges and roadways throughout the country" (Group, 2006). The Israeli behaviour and attitude during the war failed to meet fundamental principles of discrimination and proportionality that went against not only Just War traditions but also international humanitarian law (Group, 2006).

According to reports, about 38 roads have been cut off by bombings, 42 bridges, many airports (including Rafiq al-Harriri International Airport), property and residential homes (including churches and mosques), several 
schools, and hospitals were destroyed. Trucks carrying medical supplies from UAE were bombed on the road. Human Rights Watch has condemned such Israel actions as "systematically failing to distinguish between combatants and civilians, which may constitute a war crime" (Parham, 2006). The mass destruction of civil lives, properties and infrastructure undermined the principle of discrimination as an essential requirement for a just war. The net result of this Israeli action only helped to strengthen the resolve of Hezbollah in the eyes of many ordinary Lebanese that an "armed Hezbollah was indispensable to protect the country against Israel (Dijxhoorn, 2017)."

\section{Conclusion}

In the light of the aforementioned discussion, it may be concluded that that while certain criteria of the jus ad bellum such as the just cause, right authority, open declaration have been met by the Israeli attack on the Lebanon, it failed to satisfy the rest of other jus ad bellum conditions as well as the jus in bello. According to the just theory of war, the Israeli were justified in pursuing Hezbollah for provoking the initial attack and accordingly declaring an open declaration of war by the competent and legitimate authorities of the Israel. However, as argued in the paper, there was no clear indication that the objectives of the war were achievable in a month from the Israeli perspective as history proved that they were unable to do it in over 15 years. In the same vein, the war was unlikely to have the right intension as it followed an unrealistic agenda. Moreover, the Israeli's failed to explore alternative means of dispute settlement and therefore breached the principle of pursuing war as a last resort according to just war traditions. The Hezbollah objective was to force Israel on to the negotiation table by enhancing their bargaining power with the captured Israeli soldiers. Not only did Israel refuse prisoner exchange but also not willing to discuss with Hezbollah which they perceive as a terrorist institution even though both Israel and Hezbollah conducted successful prisoner exchange in 2004. The war also awfully failed to fulfil the dual conditions of jus in bello namely proportionality and discrimination. The damage and harm inflicted on Lebanon and Hezbollah far exceeded the wrong that the war set about to rectify in the first place. Hezbollah killed 3 Israeli soldiers and captured two; Israeli killed more than 1200 Lebanese citizens and lost over 100 Israeli citizens in action without achieving its war aims. By the end of 2007, Israel failed to rescue the two soldiers abducted by Hezbollah who remained under latter's custody (Gray, 2008). The wanton destruction and systematic targeting of civilians and civil infrastructure negated the principle of discrimination between combatants and non combatants. In the light of the aforementioned, it may be concluded that the Israeli war on Lebanon between July and August 2006 constituted an unjust war.

\section{Acknowledgment}

The authors would like to thank the MOE and University Technology of Malaysia (UTM), Research Management Centre (RMC), for 16H48 grant that have supported this research.

\section{References}

Arkin, W. M. (2011). Divining Victory: Airpower in the 2006 Israel-Hezbollah War. Lulu.com.

Bellamy, A. J., Bleiker, R., Davies, S. E., \& Devetak, R. (2007). Security and the War on Terror. Taylor \& Francis.

Berman, J., Steinberg, G. M., \& Herzberg, A. (2012). Best Practices for Human Rights and Humanitarian NGO Fact-Finding. Martinus Nijhoff Publisher.

Bouckaert, P., Watch, H. R., \& Houry, N. (2007). Why They Died: Civilian Casualties in Lebanon During the 2006 War. Human Rights Watch.

Bowyer, D. (2008). Just War Doctrine: Relevance and Challenges in the 21st Century (PhD). Cranfield University Cranfield University

Bush, P. (2006). President Bush Delivers Remarks on the War on Terror [Press release]. Retrieved from http://www.washingtonpost.com/wp-dyn/content/article/2006/09/05/AR2006090500656.html

Cordesman, A. H., \& Sullivan, W. D. (2007). Lessons of the 2006 Israeli-Hezbollah War. CSIS Press.

Dijxhoorn, E. (2017). Quasi-state Entities and International Criminal Justice: Legitimising Narratives and Counter-Narratives. Taylor \& Francis.

Engdahl, O., \& Wrange, P. (2008). Law at War: The Law as it Was and the Law as it Should Be. Liber Amicorum Ove Bring: Brill.

Erlanger, S. (2007, January 3). Israeli Admits Big Errors in Lebanon War, but Won't Resign. The New York Times. Retrieved from http://www.nytimes.com/2007/01/03/world/middleeast/03mideast.html 
Fattah, H. M. (2006, July 14). Israel Blockades Lebanon; Wide Strikes by Hezbollah. New York Times. Retrieved from http://www.nytimes.com/2006/07/14/world/middleeast/14mideast.html

Finnis, J. (1996). The Ethics of War and Peace in the Catholic Natural Law Tradition. In T. Nardin (Ed.), The Ethics of War and Peace. Princeton: Princeton University Press.

Gleis, J. L. (2011). Withdrawing Under Fire: Lessons Learned from Islamist Insurgencies. Potomac Books Incorporated.

Gray, C. D. (2008). International Law and the Use of Force. Oxford University Press.

Group, I. C. (2006). Israel/Palestine/Lebanon: Climbing Out of the Abyss. Retrieved from https://www.crisisgroup.org/middle-east-north-africa/eastern-mediterranean/israelpalestine/israel-palestine-1 ebanon-climbing-out-abyss

Holmes, R. L. (1992). Can War be Morally Justified? The Just War Theory. In J. B. Elshtain (Ed.), Just War Theory. Oxford: Blackwell.

Institute, S. I. P. R. (2007). Armaments, Disarmament and International Security. Oxford University Press.

John, C., \& Ford, S. J. (1970). The Morality of Obliteration Bombing. In R. A. Wasserstrom (Ed.), War and Morality. California: Wadsworth Publishing Company.

Lee, R. (2006). The History Guy: Site Map. History Guy. Retrieved from http://www.historyguy.com/israel-lebanon_war_2006.html

Levitt, M. (2015). Hezbollah: The Global Footprint of Lebanon's Party of God. Georgetown University Press.

Matthews, M., \& Institute, C. S. (2008). We Were Caught Unprepared: The 2006 Hezbollah-Israeli War. U.S. Army Combined Arms Center, Combat Studies Institute Press.

McDermott, T. S. (1989). Summa Theologiae: A Concise Translation. Christian Classics.

Norton, A. R. (2009). Hezbollah: A Short History. Princeton University Press.

O’brien, W. V. (1992). The Challenge of War: A Christian Realist Perspective. In J. B. Elshtain (Ed.), Just War Theory. Oxford: Blackwell.

Parham, R. (2006). Human Rights Watch Says Some Israeli Attacks Constitute War Crimes. Retrieved from http://www.ethicsdaily.com/human-rights-watch-says-some-israeli-attacks-constitute-war-crimes-cms-7718

Press, A. (2006, July 24). U.N. Chief Accuses Hezbollah of 'Cowardly Blending' Among Refugees. Fox News. Retrieved from http://www.foxnews.com/story/2006/07/24/un-chief-accuses-hezbollah-cowardly-blendingamong-refugees.html

Pressman, J. (2006). The United States and the Israel-Hezbollah War. Middle East Briefs Brandeis University Crown Center for Middle east Studies (No. 13), 1-7.

Ramsey, P. (1992). The Just War According to St. Augustine. In J. B. Elshtan (Ed.), Just War Theory. Oxford: Basil Blackwell Ltd.

Reynolds, M. (2005). Epiphany. Black, Proud \& Beautiful, Incorporated.

Saleh, M. (2007). The Palestinian Strategic Report 2006. Al-Zaytouna Centre for Studies \& Consultations.

Shalom, S. R. (2006, August 7). Doesn't Israel have the right to defend itself? Retrieved from $\mathrm{http}: / /$ www.antikriegsforum-heidelberg.de/palest/hintergrund/question_answer_shalom.html

Sorabji, R. (2006). Just War from Ancient Origins to the Conquistadors Debate and its Modern Relevance. In R. S. a. D. Rodin (Ed.), The Ethic of War: Shared Problems in Different Traditions. Aldershot: Ashgate Publishing Limited.

Sorabji, R., \& Rodin, D. (2006). Introduction. In R. S. D. Rodin (Ed.), The Ethic of War: Shared Problems in Different Traditions. Aldershot: Ashgate Publishing Limited.

Tal, A. (2006, July 28). Justified, Essential and Timely. Haaretz Daily Newspaper. Retrieved from http://www.haaretz.com/justified-essential-and-timely-1.193934

Turner, J. ( 1984). Can Modern War be Just? New Haven: Yale University Press.

Young, M. (2010). The Ghosts of Martyrs Square: An Eyewitness Account of Lebanon's Life Struggle. Simon \& Schuster. 


\section{Copyrights}

Copyright for this article is retained by the author(s), with first publication rights granted to the journal.

This is an open-access article distributed under the terms and conditions of the Creative Commons Attribution license (http://creativecommons.org/licenses/by/4.0/). 